\title{
Truck Drivers in the Grey Area between Employment and Self-employment: Swedish Experiences'
}

\section{Annette Thörnquist²}

Associate Professor of History, Affiliated Researcher at the Research Institute for Work, Technology and Culture, (Forschungsinstitut für Arbeit, Technik und Kultur, F.A.T.K.), Tübingen

\begin{abstract}
The paper addresses the problem of fraudulent contracting of work in the Swedish road freight transport industry with a focus on false (bogus) self-employment. The aim is to discuss the wider social context of the problem and to illustrate the significance of the mandatory Swedish notion of employee when identifying and tackling misclassification of drivers' employment status. By analyzing a case in this industry that has been tried in the Swedish Labor Court, and a related case that resulted in conciliation, the paper illustrates both the strength and limitation of labor law for counteracting disguised employment. The study also exemplifies why the notion of employee has been an argument against new regulations aimed to protect workers in the grey area between employment and self-employment. In addition to written sources, the paper draws upon interviews with informants from the Swedish Transport Workers' Union, the industry and the Swedish Tax Agency.
\end{abstract}

\section{KEYWORDS}

false (bogus) self-employment / fraudulent contracting of work / labor law / misclassification I the notion of employee / regulatory arbitrage / road freight transport industry / Sweden

\section{Introduction}

raudulent contracting of work in the grey area between genuine forms of employment and self-employment is a source of low-wage competition and social dumping. ${ }^{1}$ The notion of fraudulent contracting of work refers to arrangements that are intended to appear as regular forms of contracts, but these contracts disguise a distinct employment relationship and/or conceal who is the real employer. In other words, 'fraudulent contracting of work constitutes an abuse of existing legal employment or contractual relationships' (Eurofound 2016, p. 7). False (bogus) self-employment (disguised employment) is one of the most evident examples of this practice. Misclassification of truck drivers as self-employed workers has been a much-discussed issue in the road freight transport industry in the 2000s, especially in the context of increasing lowcost competition within the enlarged European Union (EU) (Thörnquist 2013, 2015; Muller 2014; Broughton et al. 2015; Haidinger 2017).

In most legal systems, including Nordic and EU labor law, there is a binary division between dependent (subordinate) employment and independent self-employment. An employee shall work under the direction and control of the employer, while a genuinely self-employed person shall operate as an independent contractor (Adlercreutz 1964;

\footnotetext{
${ }^{1}$ You can find this text and its DOI at https://tidsskrift.dk/njwls/index.

${ }^{2}$ Corresponding author: Annette Thörnquist. E-mail: annette.thornquist@bredband.net.
} 
Källström 2002; Engblom 2003; Verhulp 2017). In practice, however, atypical arrangements in the grey area between these main categories have become more and more common along with structural changes in the organization of production and work, including the use of new technology, new business strategies and increasing internationalization of the labor market (Collins 1990; Supiot 2001; Perulli 2003; Muehlberger 2009; Eurofound 2013, 2016).

In the 'grey area', we find dependent self-employment, referring to own-account self-employed service providers, who may use their own tools and equipment and take entrepreneurial risk (e.g., truck drivers with own trucks) but who do not operate independently in relation to the principal (often one single principal) (ILO 2003; Muhlberger 2007; Pedersini \& Coletto 2009). Sometimes the principal is worker's the former employer, who thus can benefit from flexibility and, at the same time, transfer risk to the worker. The other category is false (bogus) self-employment, that is, subordinate employment disguised as self-employment. False self-employed workers are formally self-employed, who are in fact working as employees, but without the rights and protection employees are entitled to in a regular contract of employment (ILO 2003; Perulli 2003; Verhulp 2017). The aim is to reduce labor costs by circumventing employers' regular responsibilities laid down in laws and collective agreements. Thus, misclassification of workers' true employment status undermines established labor standards and implies a high risk of precarious work and labor abuse. In addition, it means unfair competition and loss of government revenue.

Work in the grey area between employment and self-employment is not a new phenomenon. Ever since the introduction of labor laws and collective agreements, there have been strategies aimed to circumvent these regulations. Ambiguous and disguised forms of employment have long been used both as a mode of exploitation and a strategy for survival in the labor market, especially in times of crisis and unemployment. Like several other so-called new forms of employment, work in the grey area is both a preand post-Fordist phenomenon (Thörnquist 2011, 2013). In the Fordist labor market regime, the norm was full-time and permanent employment (at least for the white male worker) in vertically integrated companies. Standard employment still refers to these criteria, while various forms of fixed-term and part-time employment, as well as the use of self-employed and temporary agency workers instead of directly employed workers, refer to 'non-standard employment' (Collins 1990; Supiot 2001; Fudge 2017).

\section{The aim of the paper}

The paper addresses the problem fraudulent contracting of work in the Swedish road freight transport industry with a focus on false (bogus) self-employment. Misclassification of truck drivers as self-employed workers has mainly been identified in nonspecialized long-haul trucking and port-trucking. As in other countries in Western and Northern Europe, road freight transport carried out by truck tractors pulling trailers and containers are highly exposed to international low-cost competition. In this sector-in Sweden commonly called 'the truck tractor sector' (dragbilsbranschen)—we also find the most interchangeable drivers. Hooking and dropping loaded trailers and containers require less communication with customers and terminal staff than most other transport operations (ETF 2013, 2015; Sitran \& Pastori 2013; Transport 2018).

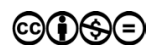


The aim of the paper is to discuss the wider social context of this practice and to illustrate the significance of the flexible and mandatory Swedish civil law notion of employee when identifying and tackling misclassification of workers' true employment status. The paper analyzes a case of false self-employment in the road freight transport industry that has been tried in the Swedish Labor Court, and a related case that the parties-a private road haulage company and the Swedish Transport Workers' Union (Transport) - eventually resolved in conciliation. The analysis illustrates both the strength and limitation of labor law when tackling issues on misclassification. The paper also exemplifies and discusses why the mandatory notion of employee has been used as an argument against new regulations aimed to protect workers in the grey area between employment and self-employment.

International research has increasingly addressed the use of dependent and false forms of self-employment as a national and international labor market phenomenon. Studies have highlighted this problem in labor-intensive industries, such as transport, construction and cleaning (e.g., Thörnquist 2013; Muller 2014; Behling \& Harvey 2015; Broughton et al. 2015). Research has also shown that dependent self-employment has become more and more common in recent decades among professionals, consultants and other high-skilled service providers, as well as among workers in arts, culture and media (Muehlbeger 2007; Kautonen \& Palmroos 2009; Eurofound 2016; Werne 2016). Moreover, fraudulent use of self-employment in the 'gig economy' has gained increasing interest among researchers (De Stefano 2016; Bögenhold et al. 2017; Eurofound 2017; Westregård 2017). Like certain other forms of nonstandard (atypical) employment, dependent self-employment does not necessarily mean precarious work, and both parties may find the arrangement advantageous. However, work in the grey area between genuine forms of employment and self-employment implies economic and social risks for the party who performs the work, especially for low-skilled workers with a weak position in the labor market (ILO 2003; Perulli 2003; Casale 2011; Behling \& Harvey 2015).

Regarding the road freight transport industry, international research has discussed the problem of fraudulent use of self-employment in the light of the deregulation and liberalization of this market and related changes in the industry structure, in business strategies and in industrial relations (Belzer 2000; Bensman 2009; 2014: Jaffee and Bensman 2016; Viscelli 2016). In European studies, the problem has mainly been related to the free movement of services and labor within the EU, including the possibility to exploit the economic and social cleft between East and West after the eastward enlargement of the Union in the 2000s (Hilal 2008; Thörnquist 2013, 2015; Muller 2014; Broughton et al. 2015; Guaman \& Loffredo 2017; Haidinger 2017).

\section{Methodology}

The paper draws upon both oral information and a variety of written sources. The analysis of the case tried in the Swedish Labor Court and cases taken to the administrative courts is based on detailed descriptions of the cases (including the parties' arguments and claims) published together with the issued judgments. Records and reports from the Swedish Tax Agency have also been used, as well as reports and comments on the cases in the media. 
Seven open interviews with informants representing Transport, the Dutch trade union FNV Bondgenoten, the Swedish Association for Road Transport Companies and the Swedish Tax Agency have given information about concrete cases as well as the broader social context of the problem of misclassification of drivers' employment status. The interviews, which were carried out face-to-face or by telephone, were centered around a few main questions about the informants' and their organizations' opinion of this problem: why and in which context it appeared, which sectors and drivers it concerned, and how the organizations dealt with the problem. The interview with the Dutch trade union officer was focused on an article in the Dutch Transport of Goods by Road Act aimed to prevent fraudulent use of self-employment. After analyzing the recorded interviews, the informants were contacted for updates and confirmation. The paper also uses reports, periodical press and other publications from Transport and the European Trade Union Federation (ETF), and from the industry. In addition, government reports and data from Statistics Sweden (SCB) and Trafikanalys (TRAFA) have been used, as well as reports and statistics from the EU. The text relates continually to relevant academic literature.

It is difficult to get statistical data on the prevalence of work in the grey area, especially false self-employment, which is an illegal practice. Comparative analyses based on the European Working Condition Surveys suggest that the share of dependent selfemployment of total self-employment is low in the Scandinavian countries. According to a recent ILO study, the share ranged from $63 \%$ in Romania, $52 \%$ in Slovakia, $43 \%$ in the United Kingdom (UK) and Austria, 42\% in Lithuania and Poland to 12\% in Sweden and $11 \%$ in Denmark in 2015 (Williams \& Lapyere 2017, pp. 17-18; cf. Eurofound 2013, p. 8). As regards false self-employment, a Swedish survey among a sample of 9000 persons aged $20-64$ years indicated that $8.6 \%$ of the self-employed contractors providing services to other companies, authorities and organizations worked under conditions similar to subordinate employees (Engblom \& Inganäs 2018). ${ }^{2}$

As in most other European and Nordic countries, the Swedish road freight transport industry consists mainly of small companies (Eurostat 2015). The share of 'local units' (companies) without employees was around 42\% in 2016, and this share has been fairly stable in the past 15 years (Statistics Sweden 2018). ${ }^{3}$ Using data from the European Labor Force Survey, Broughton et al. (2015) estimated that $6 \%$ of the Swedish heavy truck and lorry drivers were solo self-employed in 2013. However, this says nothing about the prevalence of fraudulent use of self-employment. The present paper does not try to answer this question either. It can be mentioned though that Transport estimated that there were around 1000 suspected cases of false self-employment in Sweden in autumn of 2012 (mainly among foreign drivers) (Harnesk 2012). The common use of multilevel subcontracting, and the fact that many foreign haulers and drivers working temporarily in Sweden are not registered in the country, make it even more difficult to assess the prevalence of the problem (Karlsson \& Herding 2016).

The paper proceeds as follows: The next section presents the broader social context of the problem of low-wage competition and fraudulent use of self-employment in the Swedish road freight transport industry. In the following section, the significance of the flexible and mandatory notion of employee when identifying and tackling misclassification of workers employment status is illustrated through concrete cases. This section also exemplifies and discusses the impact of the notion when considering new reforms aimed to protect workers in the grey area. The last section includes the concluding remarks. 


\section{A deregulated and internationalized road freight transport market}

What then can be said about the broader social context of the problem of fraudulent use of self-employment in the Swedish road haulage industry? When addressing this question, it is important to consider the long-term development of the deregulation and internationalization of this market, as well as the problem of low-wage competition in the enlarged EU.

Most countries in the Western World regulated the growing road freight transport industry in the wake of the Great Depression in the early 1930s in order to curb oversupply and destructive competition. The aim was also to protect the rail freight transport sector from low-cost road transport. Governments introduced various forms of market restrictions, such as entry control, capacity control and price control (OECD 1997; Belzer 2000). The intra-European road freight transport was strictly regulated as well, mainly through bilateral agreements (Bayliss 1998). This system remained for several decades, despite the fact that the Treaty of Rome (signed in 1957) prescribed a free transport market in the European Economic Community (EEC). However, it would take over 25 years, and a Judgment in the European Court of Justice (ECJ), before the process of liberalization started in earnest. ${ }^{4}$ Along with the establishment of the EU Single Market, all quantitative restrictions that could inhibit full and equal access to the internal road freight transport market had to be lifted by the end of 1992 at the latest (Council Regulation EEC 1841/88). Cabotage (domestic transport carried out by foreign haulers) was to be gradually liberalized until 1998 (OECD 1997; Bayliss 1998; Buelens \& Michielsen 2016). In the 1990s, most Western European countries deregulated their domestic road freight transport markets as well. In Sweden and in the UK, however, this process had started already in the 1960s (Kritz 1976; Bayliss 1998).

Deregulation and internationalization of the road freight transport market have contributed to a strong decline in international transport performed by Swedish haulers. In 2015, international transport accounted for $8 \%$ of the total transport carried out by Swedish trucks in terms of ton kilometers (and 2\% in terms of ton), most of it transport between Sweden and Norway (TRAFA 2017, pp. 9-13). Moreover, the share of foreign trucks operating on the domestic Swedish transport market has increased significantly (Sternberg et al. 2015; Transport 2018).

Traditionally, freight forwarders have a central role in the Swedish road freight transport sector. The transport and forwarding companies AB Svenska Godsbilcentraler (ASG) and Bilspedition $A B$ were long the main Swedish logistics, but at the turn of the century 2000 these companies were included in the German multinationals DHL and Schenker. The interviewed representatives for both the industry and the trade union consider that large forwarding agencies contribute to low-cost competition by pressing down transport prices, especially in the 'truck tractor sector' (Interview 1, 2, 3, 4; cf. Swedish Television 2013). However, the Industry Director at the Swedish Association for Road Transport Companies also emphasizes structural problems in this sector, such as oversupply and destructive competition. According to the Industry Director, many owner-drivers (self-employed) with a truck tractor have not been prepared to make the investments needed to pursue their business in a commercially sustainable way. Instead, they compete on the spot market, sometimes accepting prices at below cost in order to 
win a contract. As these owner-drivers often are strongly dependent on a single principal (a forwarding agency or a transport company), they operate as dependent self-employed workers rather than independent contractors. Thus, they contribute to the problem of price dumping by exploiting themselves. To quote the Industry Director: 'Literary, many owner-drivers drive themselves into poverty' (Interview 1).

\section{Regulatory arbitrage}

Many researchers have emphasized that market liberalization and economic integration in the EU have not been followed by a similar process of social harmonization (Scharpf 2009; Sitran \& Pastori 2013; Bernaciak 2014; Cremers 2015; Buelens \& Michielsen 2016). The possibility to exploit the difference between various national social and fiscal regimes (regulatory arbitrage) has facilitated the practice of social dumping in the EU (Berntsen \& Lillie 2015). 'Regime shopping' has become common, especially after the enlargement of the EU into Central and Eastern Europe in the 2000. The road freight transport market has been mentioned as an illustrative example of this problem (Hilal 2008; Cremers 2014; Buelens \& Michielsen 2016). Haulers in Northern and Western Europe use drivers from the new EU Member States in the former Eastern Bloc, while haulers in these regions, whose main competitive advantage is low labor costs, increasingly use drivers from countries outside the EU (ETF 2013, 2015; Transport 2018). Another variant is to establish a subsidiary or a branch (often a letter-box company) in the newer EU countries and recruit drivers from non-EU countries to work in the West (Hilal 2008; Cremers 2014; Kummer et al. 2014; McGauran 2016: Transport 2018).

The informants representing the trade unions and the industry all emphasize that these practices (including many variants) strongly affect the Swedish road freight transport market as well. According to the leader of Transport's road haulage section in Gothenburg, approximately $90 \%$ of the drivers carrying out port-trucking in the region are drivers from Eastern Europe and the Balkans working mainly for foreign road haulage companies, but sometimes also for Swedish companies.

Today, many trucks are registered in Bulgaria, while the drivers mainly come from North Macedonia. They have both a Macedonian and Bulgarian citizenship so they can work freely in the EU. They often live in the trucks for months and they are paid a fraction of the Swedish wage level. By crossing the borders to Norway or Denmark once a week, the trucks can carry out domestic transport for longer periods in Sweden without formally breaking the EU regulation on cabotage. (Interview 2)

This pattern can also be found around other big ports, such as in the Öresund area, as well as around the inland terminals for combined (multimodal) transport. Truck transport accounts for a shorter leg at the beginning and end of the transport chain. Haulers who have access to the occupation and to the market for transport of goods between the EU Member States are entitled to carry out these legs, which also may include the crossing of a frontier (Council Directive 92/106/EEC, Article 4). Hence, many foreign haulers constantly perform cabotage or combined transport in the Scandinavian region (Interview 2 and 3, Sternberg 2014; Transport 2018).

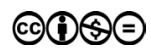


Drivers carrying out these forms of transport are generally paid on the basis of the (low) statutory minimum wages in their home countries in the former Eastern Bloc or in the Balkans, and on top of that distance-based pay and daily allowances (which are not subject to social security contributions). Thus, while the haulers can strongly reduce labor costs, the system means precarious work and poor social protection of the drivers (Interview 1, 3; CNR 2016; Haidinger 2017; Transport 2018). Payment per mile or on the basis of the amount of load is not allowed in the EU, 'if such payments challenge road safety and/or encourages infringement of social regulations' (Regulation EC No 561/2006, Article 10:1). However, this formulation is vague, making the regulation easy to circumvent.

Fraudulent use of self-employment in the road freight transport market has been identified to various extent in different countries in the EU (Broughton et al. 2015; Haidinger 2017). In Sweden, this practice has been found mainly among foreign haulers operating temporarily in the country, and among Swedish haulers who have recruited self-employed drivers from the newer EU countries in Central and Eastern Europe (Thörnquist 2013, 2015; Karlsson \& Herding 2016). The cases discussed below concern the latter.

\section{Identifying and tackling misclassification of drivers}

Researchers have increasingly discussed whether the binary divide between employment and self-employment really corresponds with the flexible forms of employment used in today's labor market (Ds. 2002:56; Engblom 2003; Källström \& Malmberg 2016; Verhulp 2017). Nonetheless, it is of central importance to keep a clear analytic distinction between these two categories. Subordinate employment and self-employment are governed by different areas of law-labor law and commercial law respectively-which implies fundamental differences in workers' rights and protection. While the purpose of labor law is to protect the weaker party in the labor market (the employee), commercial law is based on the rationale of the market forces (Perulli 2003).

The civil-law notion of employee demarcates the personal scope of labor law and in principle also the collective agreement. In Sweden, as well as in the other Nordics, the notion of employee is wide and flexible and can adjust to structural changes in the labor market. This helps to protect workers with an unclear or disguised employment status. Moreover, the notion is mandatory, which implies that the courts' opinion of an employment relationship takes precedence over the opinion of the contracting parties. This helps to prevent misclassification of workers and circumvention of labor law legislation (Källström 2002; Engblom 2003; Rönnmar 2004; Sigeman \& Sjödin 2017). The Swedish Employment (Co-Determination in the Workplace) Act (Medbestämmandlagen, $\mathrm{MBL}$ ), which regulates the relationship between employers and employees, also covers persons who are not formally employed but work under similar conditions as employees ('dependent contractors'). ${ }^{5}$

In unclear cases, the Swedish Labor Court shall ultimately decide the true employment status of a worker on a case-by-case procedure taking all relevant aspects into consideration. As in most other countries, the Swedish and Nordic courts use a set of criteria in this process. Among the criteria indicating a regular employment relationship are: that there is an agreement between the parties; that the worker performs the work 
personally for a certain period of time and in exchange for payment; that the worker is subordinated to the management and control of the employer; and that the employer provides the worker with tools, machinery and raw material and bears the financial and entrepreneurial risk in the production (Adlercreutz 1964; Källström 2002; Sigeman \& Sjödin 2017). As Verhulp (2017, p. 5) points out, the most important aspects when evaluating whether a person is genuinely or falsely self-employed are ' 1 ) whether there is legal subordination between the parties, 2) whether the person runs a financial and commercial risk and 3) to what extent a person forms part of and is embedded in the economic unit or business of the employer'.

\section{An important test case}

Over the past 10 years, Transport and the Swedish Tax Agency have both been involved in longstanding legal disputes with a large road freight transport company, a family company owned by a married couple. ${ }^{6}$ The company, which was declared bankrupt in 2017, had a truck fleet of 120-145 truck tractors but no employed drivers. Instead, the hauler recruited self-employed drivers from the newer EU countries (mainly from Poland) to work temporarily in the company. The trade union, however, considered that the drivers worked in fact as employees, and that they were deliberately misclassified as self-employed. ${ }^{7}$ This case, which gained great public attention, illustrates very clearly the significance of the mandatory notion of employee when identifying and tackling misclassification of workers' employment status.

The company had staffed the trucks with self-employed drivers from the former Eastern Bloc, mainly from Poland, since 2005. The drivers generally worked in periods of six months. After two months in their home countries, they returned for a new period of work. This also meant that they did not pay income tax in Sweden (Thörnquist 2013). In 2010, the owners registered a new company, a staffing and forwarding agency (hereinafter 'the staffing agency'). According to the contract between the companies, the role of the new company was to provide the haulage company with 'driver services', which in practice meant that the staffing agency should intermediate self-employed drivers from the newer EU Member States to the hauler. ${ }^{8}$ Even though Transport as well as the Tax Agency had begun to pay special attention to haulage companies with several truck tractors but no employed drivers, the owners did not hide the purpose of their business idea. For example, they made no secret of the fact that they could save around $50 \%$ of the labor cost for employed Swedish drivers by using self-employed Polish drivers (Swedish Television 2011). In a press interview in the autumn of 2012, one of the owners (also the managing director) declared:

For a haulage company carrying out domestic transport delivering parcels, for example, it is still possible to have Swedish drivers. The trucks start in the morning and return back home in the evening. Our trucks, on the other hand, can be on the road for a couple of weeks, and this means quite another cost level, including allowances with all it entails. It is simply not possible to use Swedish drivers. ${ }^{9}$

In November 2012, the trade union took the family company to the Swedish Labor Court claiming infringement of the collective agreement. ${ }^{10}$ The concrete case concerned 
the employment status of a Polish driver, who had lived in Sweden for some time, and who had worked in the haulage company for three months in the summer of 2011. In the autumn, the driver contacted Transport claiming that the employer had misclassified him as self-employed, even though he had worked as an employee during the whole period. According to the driver, the haulage company had employed him in June, but after some weeks, the managing director had told him to register an enterprise in Poland and sign a contract for services ${ }^{11}$ with the company's staffing agency to get paid for the work. The managing director, on the other hand, maintained that the company had engaged the driver as a self-employed subcontractor from the beginning. Neither the driver nor the hauler was organized, but the company had signed a so-called application agreement (hängavtal) with Transport in 2005. This meant that the trade union could claim infringement of the collective agreement. ${ }^{12}$ When negotiations between the central social partners failed, the trade union decided to take the case to the Labor Court requiring the family company to pay SEK 400.000 in damages.

The trade union, which had the burden of proof (together with the driver), emphasized that the driver had used the company's truck and the other equipment needed to carry out the work, and that he had not taken own economic or entrepreneurial risk. Nor had he been able to work for any other client during the summer. Moreover, the union considered that the driver had entirely worked under the management and control of the haulage company. The role of the staffing agency had only been to mediate the drivers' payment in order to conceal the fact that the haulage company was the real employer. Transport therefore claimed that the driver had worked as an employee in the haulage company. ${ }^{13}$ Referring to these criteria, the Labor Court came to the same conclusion. In the judgment that was issued in December 2013, the Court declared:

According to the Labor Court, the haulage company cannot escape the mandatory notion of employee by signing a contract for services with the driver via the other company and by letting this company handle the payment for the work. ${ }^{14}$

This case illustrates very clearly the significance of mandatory notion of employee when assessing a worker's true employment status and tackling cases of supposed misclassification. Neither the trade union nor the Labor Court considered that the agreement between the driver and the staffing agency proved that the driver had worked as an independent contractor. Instead, they made an overall assessment of his working conditions, taking into account all relevant circumstances. Westregård (2016, p. 203) emphasizes that an important evidentiary fact for the Labor Court's final judgment was that the driver had reason to believe that he had worked as an employee under the haulage company.

The judgment was a precedent and a victory for the driver and for the trade union, even though the union only received one-fourth of the required amount of damage. However, the judgment did not put an end to the use of nominally self-employed Eastern European drivers, neither in the family company nor among other haulage companies which had adopted the same business idea.

Transport intended to pursue a second case in the Labor Court comprising the other drivers from Central and Eastern Europe (around 135 drivers), who worked in the family company under the same conditions as the above-mentioned Polish driver. Again, the trade union claimed infringement of the collective agreement, requiring SEK 20 Million in damage this time. However, since no one of these drivers was willing to participate in 
the process, and the Labor Court clearly declared in the judgment of the first case that issues on workers' employment status must be tried on a case-by-case basis, Transport had to withdraw this case and agreed to resolve the dispute through conciliation (Interview 3; Örneborg 2014).

This example shows that taking suspected cases of false self-employment to court can be a complicated matter for trade unions, as workers- not least labor migrantsmay hesitate to participate in fear of losing their jobs (cf. Engblom \& Inganäs 2018; SOU 2018, p. 49). While the first case exemplifies the strength of the mandatory notion of employee and how it can be used to protect workers from being misclassified, the planned second case illustrates the limitation of labor law in this sense, as each case must be tried individually-even in cases where workers work under the same conditions in the same company. This also means that the individual worker must be prepared to participate in the legal process. The chairman of Transport made a comment on this fact in a press interview:

The judgment indicates very clearly that we must show in every single case that there really is a disguised employment relationship. This is a prevalent practice, but it is very difficult to prove. If we can't bring drivers to declare in court that they are false self-employed workers, we can't do much. ${ }^{15}$

However, the chairman, as well as the trade union lawyer and the international expert at Transport's head office in Stockholm, also emphasized that the existence of a precedent improved the trade union's possibilities to handle issues on misclassification of drivers' employment status through negotiations (Interview 4; Lindkvist 2014; Örneborg 2014).

The drivers' reluctance to participate in the case Transport planned to pursue on their behalf illustrates the complex relationship between work in the grey area as a mode of exploitation and a strategy for survival. The fact that Transport could not realize this plan, also for legal reasons, helps to explain why the family company and a number of other haulers continued to use nominally self-employed drivers from the former Eastern Bloc. At the same time, the Swedish Tax Agency launched several projects aimed to curb evasion of taxes and social security contributions in the road freight transport industry, including targeted controls of single companies (Interview 5, 6; Karlsson \& Herding 2016).

\section{Offensive tax controls}

The Swedish Tax Agency and the administrative courts use largely the same set of criteria as the Labor Court when assessing whether a person is employed or self-employed. As regards issues on who is responsible for paying social security contributions, a principal or client can be obliged to pay social fees for both employed and self-employed workers who lack A1 forms, as well as for self-employed who are not registered for Swedish business tax (F-tax) and for self-employed who in fact work as employees. As Westregård (2016, p. 203) has pointed out, 'social security legislation and social fees might play a more important part than labor law when dealing with the problem of false self-employed in the road haulage industries'. Moreover, in tax law, the employer has the burden of proof.

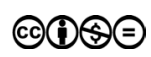


The Tax Agency's targeted controls of companies in the road freight transport industry, which resulted in an increasing number of amended tax assessments, support this suggestion. As regards the family company, the Tax Agency considered that the vast majority of the self-employed drivers from Central and Eastern Europe had worked under conditions essentially similar to those of employed workers. With few exceptions, the drivers could neither present F-tax certificates nor A1 forms showing that they were covered by the social security legislation in their home countries or elsewhere. In general, they did not work as self-employed in their home countries either. This meant that the owners of the haulage company and the staffing agency had to pay social security contributions for these drivers as they had performed the work in Sweden. In November 2012, the Tax Agency required the haulage company to pay over SEK 10 million for unpaid employer contributions and tax surcharge (Lindkvist 2012). Half a year later, the staffing agency was required to pay over SEK 14 million. Soon afterwards, the company filed for bankruptcy (Blomquist 2015).

The owners contested both these decisions in Administrative Court, but the judgments were in favor of the Tax Agency. Among other things, the Court emphasized that the drivers had used the company's trucks and other equipment needed to carry out the work, that they had worked under the direction and control of the haulage company, and that they had not been able to have any other assignments when working in the company. As regards the staffing agency, the Court made a certain reduction of the damage, as some more drivers had presented A1 certificates. ${ }^{16}$ Finally, the Administrative Court of Appeal confirmed the decisions. ${ }^{17}$

Despite the severe economic consequences, the owners established a new labor market intermediary, from which they should hire self-employed drivers recruited from central and Eastern Europe. Officially, two members of the administrative staff had started the company, but the managing director of the haulage company owned the capital stock. In addition, the company used staffing agencies in Poland, Romania and the UK. After a new meticulous revision of this version of the business model, including control of bank accounts, book-keeping, tachographs and driving logs, the Tax Agency concluded that the only role of the Swedish staffing agency, as well as the labor market intermediaries situated abroad, was to mediate the payment from the haulage company to the drivers, and thus conceal that the drivers were, in fact, employed in this company. ${ }^{18}$ As a result, the Tax Agency required the company to pay another SEK 5.8 million for unpaid employer contributions and tax surcharge (Blomquist 2016).

The Tax Agency's drive in the road freight transport sector also revealed several other haulage companies, which used or had used the same business idea as the family company. Most of these haulers had recruited self-employed drivers from Central and Eastern Europe via own or external intermediaries (in practice letter-box companies) to conceal the drivers' real employment status (Interview 5; Karlsson \& Herding 2016; Andersson 2017). The Tax Agency has therefore required an increasing number of employers to pay large sums of money for unpaid social security contributions. Moreover, the hundreds of foreign drivers, who have worked in these companies, or in the family company, have to pay Swedish income tax retroactively. ${ }^{19}$ Several companies have appealed to the administrative courts, but with few exceptions, the judgments have been in favor of the Tax Agency (have Interview 5, 6; Blomquist 2015; Karlsson \& Herding 2016; Norberg 2016; Andersson 2017). 


\section{The mandatory notion of employee and proposals on new regulations}

As has been illustrated above, the mandatory notion of employee implies that the opinion of the courts takes precedence over the opinion of contracting parties in legal disputes on a worker's employment status. Moreover, the flexible character of the notion implies that it can adjust to changes in the labor market. These characteristics are of central importance for the protection of workers in the grey area. Experts and lawmakers have therefore been restrictive when it comes to proposals on new regulations aimed to protect workers in the grey area. For example, the idea of extending the protection of labor law and social security law (in part or as a whole) to a 'third legal category' between employment and self-employment has not gained support among Swedish lawmakers (Legislative Inquiry Ds 2002, p. 256).

Another example of direct relevance to the road freight transport industry concerns the possibility to introduce the so-called Dutch model for preventing fraudulent use of self-employment and temporary agency work in this industry. The Dutch model refers here to the Dutch Transport of Goods by Road Act (Article 2.11), which states that haulage companies must employ the drivers they engage to drive their trucks. The parties shall set up a formal agreement stating (1) that the hauler shall bear the cost and entrepreneurial risk for the transport, and (2) that the driver shall work as an employee under the management and control of the hauler. ${ }^{20}$ Haulage companies can engage subcontractors with own trucks and own transport licenses that entitles them to carry out transport in the EU. They may also use temporary work agencies at peak times, but the agencies must be certified and the drivers' wages and working conditions must be in line with the Dutch collective agreement. According to the trade union FNV Bondgenoten, the regulation has worked successfully, and the social partners have jointly defended the model against 'neoliberal criticism'. The opponents' main argument has been that the Act challenges the free and non-discriminatory EU transport market. However, a parliamentary investigation that evaluated the regulation at the beginning of the 2010 came to the conclusion that it was consistent with EU law and should be retained (Interview 7).

The Dutch model has gained interest in other EU countries as well, for example, in Sweden. On the recommendation of the Transport Committee in the Swedish parliament, Riksdagen, the center-right alliance government (in office 2006-2014) commissioned the Swedish Transport Agency in 2012 to look over the possibility to introduce a similar regulation in Sweden. ${ }^{21}$ However, the Transport Agency did not recommend such a reform, referring to the protection the mandatory notion of employee and the Employment Protection Act (Lagen om anställningsskydd) provide. The Transport Agency underlined that the mandatory character of the notion of employee implied that the contracting parties were not entitled to decide the true employment status of a person on their own. In fact, the reform would mean a stronger emphasize on the contract between the parties. Accordingly, the Transport Agency found that the Dutch model was not consistent with the legal practice in the Swedish Labor Court. The government rejected the idea on the same grounds. The government also feared that the Dutch model would limit the entrepreneurial freedom, and probably challenge the freedom of movement of labor and services in the EU as well. ${ }^{22}$

In the 2014 general election campaign, the Social Democratic Party (SAP) and the Swedish Trade Union Confederation (LO) launched a 10-point program for Law and Order in the Labor Market (Ordning och reda på arbetsmarknaden), which suggested 
the introduction of the Dutch model (LO 2014). However, the red-green government that took office after the general election did not make any attempts to introduce the model. The Minister of Infrastructure declared in 2015 that the government had no such plans. In line with the Transport Agency and the former center-right alliance government, the Minister considered the model was not consistent with the mandatory Swedish notion of employee. Instead, the government should prioritize other reforms to promote fair transport, such as reinforced road-side checks and a stricter customer responsibility when purchasing transport services. ${ }^{23}$

For some years now, the trade union Transport runs an own permanent project, called Law and Order in the Road Haulage Industry (Ordning och reda i akeribranschen). The aim is to combat and prevent fraudulent use of self-employment and temporary work agencies, as well as other fraudulent practices in the liberalized and internationalized road freight transport market (Transport 2018). According to the leader of the project, the use of self-employed foreign drivers in the Swedish road freight transport companies has decreased in the past few years. He considers that Transport's and the Swedish Tax Agency's intense work against unfair competition and social fraud, and the fact that there exists a precedent in the Labor Court, have contributed to this development. The project leader also emphasizes that Swedish and foreign road freight transport companies use other ways to press down labor costs by practicing increasingly advanced forms of regime shopping and exploiting loopholes in EU regulations applying to the road freight transport market, such as the rules on cabotage, combined transport and the posting of workers.

\section{Concluding remarks}

The aim of this paper was to illustrate through concrete cases the significance of the flexible and mandatory Swedish notion of employee when identifying and tackling misclassification of truck drivers as self-employed workers. The paper also discussed why and in which sectors this form of fraudulent contracting of work has appeared in the road freight transport industry in recent decades. Regarded in the wider social context, the use of false self-employed drivers can be related to the free movement of labor and services and the possibility exploit the economic and social cleft between East and West in the EU. The deregulation and liberalization of the road haulage market and the lack of social harmonization within the EU help to explain the complex background to the problem as well.

In the Swedish road freight transport industry, the use of false self-employment has mainly been identified in nonspecialized long-distance trucking and port-trucking carried out by truck tractors pulling trailers and containers from one location to another. This sector (the truck tractor sector), in which drivers are easily interchangeable, is also subject to intense international low-cost competition and hard price pressure from freight forwarder. Moreover, the sector suffers from internal structural problems, such as oversupply and destructive competition. Among other things, many owner-drivers are dependent self-employed rather than independent contractors.

The paper focused on Swedish haulers who have recruited self-employed drivers from Central and Eastern Europe-drivers who have in fact worked as employees, but without the rights and protection genuinely employed workers are entitled to. In this 
way, the haulers have been able to reduce labor costs and gain flexibility. The analysis indicated that the involvement of labor market intermediaries, which often have been revealed as 'letter-box companies', has been a vital part of this practice. The increasing use of letter-box companies is currently as one of the most urgent issues in the European road haulage market (Cremers 2014; McGauran 2016; European Parliament 2017; Transport 2018).

The case of false self-employment that was tried in the Swedish Labor Court illustrated very clearly the significance of the mandatory Swedish notion of employee when identifying and tackling disguised employment. The Labor Court did not consider that the contract for services between the Polish driver and the haulage company's staffing agency proved that the driver really had worked as an independent contractor. Instead, the Court made a holistic assessment of the relationship between the haulage company, the staffing agency and the driver, taking into account all relevant aspects of his working conditions, including the driver's own conception of his employment status. The second case, which Transport could not pursue in the Labor Court as each case must be tried individually, illustrated that the crucial issue for the trade unions when taking cases of false self-employment to court is that the individual worker really is prepared to participate in the legal process.

The fact that no one of the other 135 self-employed Eastern European drivers in the haulage company was willing to take part in such a process also illustrates the complex relationship between work in the grey area as a mode of exploitation and a survival strategy, including the dilemma it implies for trade unions when tackling disguised or ambiguous forms of employment. This is an old problem that has become even more complicated in today's internationalized labor market. In the Swedish road freight transport industry, as well as in construction (Thörnquist 2013, 2015), suspected cases of false self-employment have mainly been found among migrant workers (cf. Broughton et al. 2015; Behling \& Harvey 2015). It is reasonable to assume that these workers fall outside international comparative surveys on the prevalence false and dependent forms of self-employment based on the European Working Condition Surveys (Eurofound 2013; Williams \& Lapyere 2017). Thus, qualitative studies are needed to get a nuanced picture of the problem in different countries and industries.

The aim of the Swedish Tax Agency's offensive controls and audits in the road freight transport industry, which also included the drivers' employment status, has naturally been to reveal and combat the evasion of taxes and social security contributions. However, the amended tax assessments, and the economic consequences for those involved in fraudulent practices, have also helped to prevent exploitation of nominally self-employed drivers.

It is easy to agree that social security legislation and social fees may sometimes play a more important role than labor law when dealing with false self-employment (cf. Westregård 2016). The Tax Agency required the family company and many other haulage companies to pay social security contributions retroactively, not only for 'selfemployed' drivers, who according to the authority had in fact worked as employees, but also for drivers who could not present an F-tax certificate or an A1 form. In addition, hundreds of foreign drivers were required to pay Swedish income tax, including tax surcharge.

The paper also exemplified why the mandatory notion of employee has been an argument among Swedish lawmakers against proposals on new legislation aimed to 
prevent exploitation of worker in the grey area. The center-right as well as red-green governments' decisions to reject idea of the 'Dutch model' for preventing fraudulent use of self-employment provided an illustrative example of this policy. It is difficult to estimate, however, if the real motive was to follow Swedish legal practice or to avoid challenging entrepreneurial freedom and the free movement of labor and services in the EU.

\section{Acknowledgments}

This work was supported by the Elin and Charles Lindley Foundation.

\section{References}

Adlercreutz, A. (1964). Arbetstagarbegreppet: om arbetstagarförhållandet och därtill hörande gränsdragningsfrågor i svensk civil- och socialrätt. (The Notion of Employee: the Employment Relationship and Related Borderline Issues in Swedish Civil and Social Law), Stockholm: P. A. Nordstedt \& Söners förlag.

Andersson, R. (2017). Fler åkerier fast i skatterazzia. (Several haulers caught in tax razzia). Trailer, January 2, 2017.

Bayliss, B. (1998). Regulations in the European road freight transport sector, Journal of Transport Economics and Policies 32(1): 113-131.

Behling, F. and Harvey, M. (2015). The evolution of false self-employment in the British construction industry: a neo-Polanyian account of labour market formation. Work, Employment and Society 29(5): 969-988. doi: https://doi.org/10.1177/0950017014559960.

Belzer, M. H. (2000). Sweatshops on Wheels: Winners and Losers in Trucking Deregulation, Oxford, UK and New York, NY: Oxford University Press.

Bensman, D. (2009). Port Trucking Down the Low Road: A Sad Story of Deregulation, New York City: Dēmos.

Bensman, D. (2014). Misclassification: Workers in the borderland. Journal of Self-Governance and Management Economics 2(2): 947-969.

Bernaciak, M. (2014). Social Dumping and the EU Integration Process. Working Paper 2014.06, Brussels: European Trade Union Institute.

Berntsen, L. and Lillie, N. (2015). Breaking the law? Varieties of social dumping. In: Bernaciak, M. (ed.) Market Expansion and Social Dumping in Europe, pp. 43-60, London: Routledge.

Blomquist, L. (2015). Andreassons överklagar. (Andreasson appeals), August 21, 2015.

Blomquist, L (2016). Ny bakläxa för Andreassons. (New rebuff for Andreasson). Transportarbetaren, August 23, 2016.

Broughton, A., Curtarelli, M., Bertram, C., Fohrbeck, A., Hinks, R., and Tassinari, A. (2015). Employment Conditions in the International Road Haulage Sector, Brussels: European Parliament, Committee on Employment and Social Affairs. Available at: http://www.europarl.europa.eu/thinktank/en/document.html?reference=IPOL STU(2015)542205.

Buelens, J. and Michielsen, L. (2016). Social dumping: a symptom of the European construction. An exploratory study of social dumping in road transport. In: Buelens J. and Rigaux M. (eds.) From Social Competition to Social Dumping, pp. 33-62, Antwerp/Cambridge: Intersentia.

Bögenhold D., Klinglmair R. and Kandutsch F. (2017). Solo self-employment, human capital and hybrid labor in the gig economy, Foresight and STI Governance 11(4): 23-32. doi: https://doi.org/10.17323/2500-2597.2017.4.23.32. 
Casale, G. (2011). The employment relationship: a general introduction. In: Casale, G. (ed.), The Employment Relationship. A Comparative Overview, pp. 1-8, Oxford: Hart Publishing \& ILO.

Collins, H. (1990). Independent contractors and the challenge of vertical disintegration to employment protection laws, Oxford Journal of Legal Studies 10 (3): 353-380. doi: https://doi.org/10.1093/ojls/10.3.353.

Cremers, J. (2014). Letter-box Companies and Abuse of the Posting Rules: How the Primacy of Economic Freedoms and Weak Enforcement give Rise to Social Dumping. ETUI Policy Brief. No 5/2014, Brussels: European Trade Union Institute.

Cremers, J. (2015). EU economic freedoms and social dumping. In: Bernaciak, M. (ed.) Market Expansion and Social Dumping in Europe, pp. 173-189, London: Routledge.

De Stefano, V. (2016). The Rise of the 'just-in-time workforce': On-demand Work, Crowdwork and Labour Protection in the 'gig-economy'. International Labour Office, Inclusive Labor Markets, Labour Relations and Working Conditions Branch, Geneva: ILO.

Engblom, S. (2003). Self-employment and the Personal Scope of Labour Law - Comparative Lessons from France, Italy, Sweden, the United Kingdom and the United States, Florence: European University Institute, Department of Law. doi: https://doi.org/10.2870/ 68969.

Engblom, S. and Inganäs, J. (2018). Atypiska företagare: Om relationen mellan företagare och deras uppdragsgivare. (Atypical Contractors: The Relationship Between Contractors and Their Clients), Stockholm: TCO.

ETF (2013). Modern Slavery in Modern Europe? An ETF Account on the Working and Living Conditions of Professional Drivers in Europe, Brussels: European Transport Workers' Federation (ETF).

ETF (2015). Fair Transport Europe. ETF vision for the future of European Transport European Transport, Brussels: European Transport Workers' Federation (ETF).

Eurofound (2013). Self-employed or Not Self-employed? Working Conditions of 'economically dependent workers', Dublin: European Foundation for the Improvement of Living and Working Conditions. Available at: https://digitalcommons.ilr.cornell.edu/cgi/viewcontent. cgi? referer=https://www.google.com/\&httpsredir=1\&article=1297\&context=intl.

Eurofound (2016). Exploring the Fraudulent Contracting of Work in the European Union, Luxembourg: Publications Office of the European Union. doi: https://doi.org/10.2806/ 708953.

Eurofound (2017). Non-standard Forms of Employment: Recent Trends and Future Prospects, Dublin: Eurofound.

European Parliament (2017). Briefing Initial Appraisal of a European Commission Impact Assessment. Road transport: Driving times, breaks, rest periods, tachographs and posting of drivers. Available at: http://www.europarl.europa.eu/RegData/etudes/BRIE/ 2017/611007/EPRS BRI(2017)611007 EN.pdf.

Eurostat (2015). Goods road transport enterprises, by number of employees (road_ec entemp).

Fudge, J. (2017). The future of the standard employment relationship: labour law, new institutional economics and old power resource theory, Journal of Industrial Relations 59(3): 374-392. doi: https://doi.org/10.1177/0022185617693877.

Guaman, A. and Loffredo A. (2017). Social Dumping in the Transport Sector, European Transport Workers' Federation (ETF).

Haidinger, B. (2017). Fraudulent Contracting of Work: Road Haulage Sector, Dublin: Eurofound.

Harnesk, T. (2012). Central förhandling om 'falsk egenföretagare' (Central Negotiation on 'false self-employment'). Transportarbetaren, August 22, 2012. http://www.transportarbetaren.se/central-forhandling-om-falsk-egenforetagare/191/. 
Hilal, N. (2008). Unintended effects of deregulation in the European Union: the case of road freight transport, Sociologie du travail 50: 19-29. doi: https://doi.org/10.1016/j. soctra.2008.07.002.

ILO (2003). The Scope of the Employment Relationship. Report V, Fifth item on the agenda, International Labour Conference, 91st Session, Geneva: International Labour Office.

Jaffee, D. and Bensman, D. (2016). Draying and picking: precarious work and labor action in the logistics sector, The Journal of Labor Society 19(1): 1-140. March 2016. doi: https:// doi.org/10.1111/wusa.12227.

Karlsson, U. and Herding, I. (2016). Åkeriverksamhet i Sverige 2015. (Road Haulage in Sweden 2015). Dnr. 410-115937-16/123, Stockholm: Skatteverket.

Kautonen, T. Vainio, P. and Palmroos, J. (2009). Involuntary self-employment in Finland: a bleak future? International Journal of Public Policy 4(4): 533-548. doi: https://doi. org/10.1504/IJPP.2009.025261 · Source: RePEc.

Kritz, L. (1976). Transportpolitiken och lastbilarna: En studie av regleringar och deras effekter. (The Transport Policy and the Trucks: A Study on Regulations and Their Effects), Stockholm: Industriens Utredningsinstitut.

Källström, K. (2002). Employment Agreements and Contract Work in the Nordic countries. In: Wahlgren, P. (ed.) Stability and Change in Nordic Labour Law. Scandinavian Studies in Law 43, pp. 77-86, Stockholm: Stockholm Institute for Scandinavian Law.

Källström, K. and Malmberg, J. (2016). Anställningsförhållandet - inledning till den individuella arbetsrätten. 4th ed. (The Employment Relationship - Introduction to the Individual Labor Law), Uppsala: Iustus.

Larsson, F. (2012). 'Vi hade inte haft personal om vi bedrivit slavhandel'. ('We would not have had any staff members if we had dealt with trafficking)'. Hallands Nyheter, October $11,2012$.

Legislative Inquiry, Ds 2002: 56. Hållfast arbetsrätt för ett föränderligt arbetsliv. (Sustainable Labor Law for a Changing Working Life), Stockholm: Arbetmarknadsdepartementet.

Lindkvist, J. (2012). Skatteverket kräver Andreassons på 10,5 miljoner. (The Tax Agency requires Andreasson to pay SEK 10.5 million), Transportarbetaren, 28 November 2012. Lindkvist, J. (2014). Transport försvarar förlikning med Andreassons. (Transport defends conciliation with Andreasson). Transportarbetaren, February 19, 2014.

LO (2014). Swedish Trade Union Confederation (LO). Press release. Socialdemokraterna och LO presenterar ordningsregler för svensk arbetsmarknad. (The social democrats and the LO present code of conduct for the Swedish labor market), February 26, 2014. Available at: http://www.lo.se/start/pressmeddelanden/socialdemokraterna och lo presenterar ordningsregler for svensk arbetsmarknad.

McGauran, K. (2016). The Impact of Letterbox-type Practices on Labour Rights and Public Revenue: Four Case Studies on the Use of Letterbox Companies and Conduit Entities to Avoid Labour Laws, Social Premiums and Corporate Taxes, Brussels: ETUC.

Muehlberger, U. (2007) Dependent Self-employment: Workers on the Border Between Employment and Self-employment, Houndmills: Palgrave Macmillan. doi: https://doi. org/10.1080/00346760701875215.

Muller, F. (2014). Cross-border mobility of bogus self-employment workers: a lack of legal framework coupled with protection of economic rights, European Labour Law Journal 5(3-4): 267-278. doi: https://doi.org/10.1177/201395251400500308.

Norberg, A-L. (2016). 'Tax Time', Stoppa Fusket, September 16, 2016. Available at: http:// www.stoppafusket.se/2016/09/16/det-regnar-skatterakningar-over-akerier-och-chaufforer/.

OECD (1997). Liberalization and Structural Reform in the Freight Transport Sector in Europe: The Freight Transport Sector in Europe, Paris: OECD Publishing.

Pedersini, R. and Coletto, D. (2009). Self-employed Workers: Industrial Relations and Working Conditions, Dublin: Eurofound. 
Perulli, A. (2003). Economically dependent/quasi-subordinate (parasubordinate) employment: legal, social and economic aspects. Public Hearing June 19, 2003, Brussels: European Parliament.

Scharpf F. W. (2009). The Asymmetry of European Integration or Why the EU Cannot be a 'Social Market Economy', KFG Working Paper Series, No. 6, Kolleg-Forschergruppe (KFG), Berlin: Free University Berlin.

SOU 2018:49. F-skattesystemet - några särskilt utpekande frågor. Delbetänkande av F-skatteutredningen (The F-tax system - some notable questions. Interim report of the F-tax inquiry), Swedish Ministry of Finance.

Sigeman, T. and Sjödin, E. (2017). Arbetsrätten — En översikt, $7^{\text {th }}$ ed, Stockholm: Nordstedts Juridik.

Sitran, A. and Pastori E. (2013). Social and Working Conditions of Road Transport Haulage. Policy Department B: Structural and Cohesion Policies, Brussel: European Parliament.

Statistics Sweden (2018). The Company Register. Available at: https://www.scb.se/vara-tjanster/foretagsregistret/aktuell-statistik-fran-foretagsregistret/.

Sternberg H., Filipiak, M., Hofmann et al. (2015). Cabotagestudien. A Study on Trucking Deregulation and Cabotage in Scandinavia and beyond, Lund: Lund University Department of Design Sciences Division of Packaging Logistics.

Supiot, A. (2001). Beyond Employment: Changes in Work and the Future of Labour Law in Europe, Oxford: Oxford University Press.

Swedish Television (2011). SVT1, Uppdrag granskning (Mission Investigate), March 30, 2011.

Swedish Television (2013). SVT1, Uppdrag granskning (Mission Investigate), March 9, 2013.

Swedish Transport Workers' Union (2018). Ordning och reda åkeribranschen. (Law and Order in the Road Haulage Industry). Available at: https://www.transport.se/paverka/paverka-internationellt/ordning-och-reda-i-akeribranschen/.

Thörnquist, A. (2011). False Self-Employment: A Topical but Old Labour Market Problem. In: Thörnquist, A. and Engstrand, Å.-K. (eds.) Precarious Employment in Perspective: Old and New Challenges to Working Conditions in Sweden. Work \& Society: 70, pp. 101-129, Brussels: P. I. E. Peter Lang Publishing Group.

Thörnquist, A. (2013). False (Bogus) Self-Employment in East-West Labour Migration: Recent Trends in the Swedish Construction and Road Haulage Industries. TheMES, Themes on Migration and Ethnic Studies, No. 41, Linköping: Linköping University Electronic Press. Available at: http://urn.kb.se/resolve?urn=urn:nbn:se:liu:diva-95803.

Thörnquist, A. (2015). False self-employment and other precarious forms of employment in the 'grey area' of the labour market, International Journal of Comparative Labour Law and Industrial Relations 31(4): 411-429.

TRAFA (2017). Lastbilstrafik 2016. Swedish national and international road goods transport 2016, Statistics 2017: 14. Available at: https:/www.trafa.se/globalassets/statistik/ vagtrafik/lastbilstrafik/2016/lastbilstrafik-2016-helar.pdf.

Transport (2018). Law and order in the haulage industry, Swedish Transport Workers' Union. Online video. Available at: https://www.facebook.com/Transportsordningochreda/ videos $/ 583593105424707 /$ ? q=ordning $\% 20$ och $\% 20$ reda $\% 20 \mathrm{i} \% 20 \% \mathrm{C} 3 \%$ A $5 \mathrm{keribran}-$ schen\&epa=SEARCH BOX.

Verhulp, E. (2017). The Notion of 'Employee' in EU-Law and National Laws. A Thematic Working Paper for the Annual Conference of the European Centre of Expertise (ECE) in the field of labour law, employment and labour market policies: The Personal Scope of Labour Law in Times of Atypical Employment and Digitalisation, Brussels: European Commission.

Werne, K. (2016). Frihetens pris. Om otryggheten i mediabranschen, (The Price of Freedom. Precariousness in the Media Industry) \# 2, Stockholm: Journalistförbundet (Swedish Union of Journalists). 
Westregård, A. (2016). The notion of 'employee' in Swedish and European Union Law: An exercise in harmony or disharmony? In: Carlson, L., Edström, Ö. and Nyström, B. (eds.). Globalisation, Fragmentation, Labor and Employment Law: a Swedish Perspective, pp. 185-206, Uppsala: Iustus.

Westregård, A. (2017). Collaborative economy - a new challenge for the social partners: In Ahlberg, N., Hertzfeldt, P. and Malmberg, J. (eds). Niklas Bruun i Sverige: En vänbok (Nicklas Bruun in Sweden: a Book of Honour), pp. 427-438, Uppsala: Iustus.

Williams, C. C., and Lapyere, F. (2017). Dependent Self-employment: Trends, Challenges and Policy Responses in the EU, Geneva: International Labour Organization (ILO).

Viscelli, S. (2016). The Big Rig: Trucking and the Decline of the American Dream, Oakland, CA: University of California Press.

Örneborg, E. (2014). 20 miljoner blev 175000 efter förlikning. (SEK 20 million reduced to SEK 175000 after conciliation), Lag \& Avtal, 19 Februari 2014.

\section{Interviews}

1 Industry Director, Swedish Association for Road Transport Companies, Stockholm. February, 2017, follow-up interview in February 2018.

2. Regional trade union officer, Transport Department 3, Gothenburg. March 2018. Follow up interview in December 2018.

3. Trade union officer and project leader for 'Law and Order in the Road Haulage Industry', Transport, June 2015; follow-up conversation per e-mail and telephone in April and December 2018.

4. International officer, Transport, Stockholm. March 2014; follow-up interview in September 2014.

5. Tax Accountant and Regional Coordinator, Advanced Economic Criminality, Swedish Tax Agency, Region West. February 2017. Follow up e-mail and telephone conversation in December 2018.

6. National coordinator, Advanced Economic Criminality, Swedish Tax Agency, Stockholm. February 2017. Follow-up e-mail conversation in November 2018.

7. Trade union officer, FNV Bondgenoten, The Netherlands. February 2017. Follow-up e-mail conversation in May 2017 and September 2018.

\section{Notes}

${ }^{1}$ As defined by Bernaciak (2014, p. 16), social dumping refers to 'the practice undertaken by self-interested market participants, of undermining or evading existing social regulations with the aim of gaining a short-term advantage over their competitors'.

2 The sample represented 3.7 million of the around 5 million employed persons in Sweden in 2015 .

${ }^{3}$ In this case, a 'local unit' corresponds to a 'company' (information from Statistic Sweden by e-mail March 14, 2019).

${ }^{4}$ In 1983, the European Parliament took the European Council of Ministers to the ECJ for not implementing a common transport policy. The process of deregulation took off in the wake of Judgment (13/83 of May 22, 1985), which was in favor of Parliament.

5 SFS 1976: 580, Section 1. 
${ }^{6}$ The married couple owned the haulage company via an own holding company.

7 Swedish Labor Court, Judgment No. 92/13, Case No. A 213/12.

${ }^{8}$ Swedish Labor Court, Judgment No. 92/13, Case No. A 213/12.

9 The managing director is cited in Larsson (2012). (The author's translation).

10 Swedish Labor Court, Judgment No. 92/13, Case No. A 213/12.

11 A contract for services refers to a commercial contract between a principal and a selfemployed person.

12 Swedish Labor Court, Judgment No. 92/13, Case No. A 213/12.

13 Swedish Labor Court, Judgment No. 92/13, Case No. A 213/12.

14 Swedish Labor Court, Judgment No. 92/13, Case No. A 213/12, p. 18. (The author's translation).

15 The chairman is quoted in Örneborg (2014). (The author's translation).

16 Administrative Court, Gothenburg, Judgment of June 24, 2014, Case No. 7932-13-794-13 2014.

${ }^{17}$ Administrative Court of Appeal, Gothenburg. Judgment June 4, 2015. Case No. 43034304 4306-14 and case No 4307-4308-14; See also The Supreme Administrative Court, Stockholm. Judgment May 4, 2016, Case No. 5122-15, 5123-15 and Case No. 51195121-15.

${ }_{18}$ Swedish Tax Agency, ref. 556569-6571 and ref. 556943-1249.

19 See, for example, the Swedish Tax Agency's amended tax assessments, January 13, 2017, ref. 601008-4173, 51000610.

20 Wet wegvervoer goederen. (the Transport of Goods by Road Act). October 30, 2008, Article 2.11 on road transport.

${ }^{21}$ Parliament Bill 2012/13 T: 361; See also Interpellation 2012/13: 48; Government Bill 2013/14: 234, p. 23.

22 Government Bill 2013/14: 234; See also debate on question raised in Riksdagen November 9, 2012.

${ }^{23}$ Ministry of Enterprise and Innovation, Registration number N2015/08588/MRT. 